Terakreditasi

Ditjen Penguatan Riset dan Pengembangan, Kemenristekdikti

Keputusan No: 21/E/KPT/2018, Tanggal 9 Juli 2018
Mei 2020, 7(2):110-118

DOI: http://dx.doi.org/10.33772/jitro.v7i2.12215

http://ojs.uho.ac.id/index.php/peternakan-tropis

\title{
Potensi Pengembangan Komoditas Peternakan di Sulawesi Tenggara
}

\author{
Siti Rahmah Karimuna*, Sri Bananiek, Syafiuddin, Waode Al Jumiati \\ Balai Pengkajian Teknologi Pertanian Sulawesi Tenggara \\ Jalan Prof. Muh. Yamin No. 89 Kendari \\ *Email korespondensi: sitirahmahkarimuna@ rocketmail.com
}

(Diterima 23-11-2019; disetujui 03-05-2020)

\begin{abstract}
ABSTRAK
Sektor pangan merupakan sektor yang menjadi prioritas di Indonesia dalam pembangunan nasional. Salah satu sub-sektor pangan yaitu peternakan. Produksi daging, telur dan susu merupakan bagian utama produksi hasil peternakan. Sub-sektor peternakan memegang peranan penting dalam pengembangan agrobisnis di Provinsi Sulawesi Tenggara. Komoditas peternakan yang diusahakan rakyat di Provinsi Sulawesi Tenggara terdiri dari 7 jenis yaitu: sapi potong, kerbau, kuda, kambing, babi, ayam dan itik. Tujuan penelitian ini adalah untuk mengetahui potensi unggulan dan penyebaran komoditi sub-sektor peternakan dan kemungkinan budidayanya di Provinsi Sulawesi Tenggara. Data dianalisis dengan menggunakan analisis location quotien (LQ) untuk mengetahui potensi pengembangan komoditas peternakan di tiap kabupaten, dengan menggunakan indikator volume produksi daging semua komoditas peternakan. Hasil penelitian menunjukkan bahwa berdasarkan potensi pengembangan komoditas peternakan diperoleh, ayam buras merupakan komoditas peternakan terunggul di Sulawesi Tenggara karena memiliki nilai LQ>1 yang tersebar di 9 kabupaten, dan kedua adalah komoditas sapi potong dan kambing dengan sebarannya di 8 kabupaten yang berbeda. Berdasarkan potensi daerah, kabupaten yang memiliki keragaman komoditas peternakan tertinggi adalah kabupaten Kolaka Utara, karena memiliki 6 komoditas yang memiliki nilai LQ>1, diikuti kabupaten Wakatobi yang memiliki 5 komoditas dengan nilai LQ>1.
\end{abstract}

Kata Kunci: komoditas peternakan, location quotient, potensi unggulan

\section{ABSTRACT}

The food sector is a priority sector in Indonesia in national development. One of the food subsectors is livestock. Meat, egg, and milk production are the main parts of livestock production. The livestock subsector plays an important role in the development of agribusiness in Southeast Sulawesi Province. Livestock commodities cultivated by the people in Southeast Sulawesi Province consist of 7 types, namely: beef cattle, buffalo, horse, goat, pig, chicken, and duck. The aim of this study is to find out the superior potential and distribution of livestock sub-sector commodities and possible cultivation in Southeast Sulawesi Province. Data were analyzed using the location quotient (LQ) analysis to determine the potential for livestock commodity development in each district, using an indicator of the volume of meat production of all livestock commodities. The results showed: 1) Based on the potential development of livestock commodities obtained, free-range chicken is the leading livestock commodity in Southeast Sulawesi because it has an LQ value>1 spread in 9 districts, and second is the Beef and Goat commodity with its distribution in 8 different districts, and 2) Based on the regional potential, the district which has the highest diversity of livestock commodities is the North Kolaka district, because it has 6 commodities that have LQ value $>1$. Followed by the Wakatobi district which has 5 commodities with $L Q$ value $>1$.

Keywords: livestock commodities, location quotient, superior potential

\section{PENDAHULUAN}

Sektor pangan merupakan sektor yang menjadi prioritas di Indonesia dalam pembangunan nasional. Hal ini disebabkan oleh pertambahan jumlah penduduk yang terus meningkat setiap tahunnya yang diiringi dengan peningkatan kebutuhan pangan dan energi di Indonesia. Salah satu sub-sektor pangan yaitu peternakan. Indonesia 
memiliki beberapa komoditas peternakan utama yang diperdagangkan di pasar internasional diantaranya daging (sapi, kambing/domba, babi, ayam), ternak hidup sumber daging (sapi, kerbau, babi, kambing), hati/jeroan, telur untuk konsumsi, dan susu. Nilai ekspor sub-sektor peternakan mengalami laju pertumbuhan rata-rata sebesar 43,8\%/tahun, sedangkan laju pertumbuhan nilai impornya meningkat $33,9 \%$ per tahun. Hal ini menunjukkan adanya kecenderungan penurunan/ defisit neraca perdagangan sub-sektor peternakan. Impor susu, ternak sapi dan daging sapi merupakan komponen sumber defisit neraca perdagangan komoditas peternakan yang terbesar, dengan jumlah yang sangat besar, sementara sumber surplus hanya ekspor ternak babi yang jumlahnya sangat kecil (Kementan, 2015).

Aspek produksi merupakan aspek yang sangat diperhatikan dalam menunjang kebutuhan pangan. Produksi daging, telur dan susu merupakan bagian utama produksi hasil peternakan. Pada tahun 2010-2014, produksi secara nasional untuk daging dan telur mengalami pertumbuhan yang baik yaitu masing masing sebesar 5,98 dan 7,08 \%/thn. Namun lain halnya dengan produksi susu mengalami penurunan sebesar $-2,73 \%$ per tahun (Kementan, 2015).

Keunggulan kompetitif suatu daerah, spesialisasi wilayah dan potensi pertanian yang dimiliki oleh daerah tersebut mampu mempengaruhi pertumbuhan sektor pertanian suatu daerah. Namun, potensi pertanian di suatu daerah tidak mempunyai arti bagi pertumbuhan pertanian daerah tersebut jika tidak ada upaya dalam pemanfaatan dan pengembangan potensi pertanian secara optimal. Oleh karena itu, pemanfaatan dan pengembangan seluruh potensi pertanian yang potensial di suatu daerah harus menjadi prioritas utama untuk digali dan dikembangkan dalam melaksanakan pembangunan pertanian daerah secara utuh (Wicaksono, 2011). Daerah Sulawesi Tenggara yang memiliki keunggulan produk peternakan yang telah diakui secara nasional.

Sulawesi Tenggara menurut peta topografi umumnya memiliki permukaan tanah yang bergunung, bergelombang, dan berbukit-bukit. Selain dari itu, memiliki daratan yang berpotensi dalam pengembangan sektor pertanian. Salah satu sektor pertanian yang dapat dikembangkan di Sulawesi Tenggara adalah komoditas peternakan. Menurut Kementerian PPN/Bappenas (2015) bahwa salah satu sumber pangan lokal Sulawesi Tenggara adalah peternakan. Namun, sub-sektor peternakan masih mengalami permasalahan. Menurut Kementerian PPN/Bappenas (2017) bahwa permasalahan utama dalam aspek peternakan adalah rendahnya produksi unggas/ternak. Produksi daging dari hewan ternak di Sulawesi Tenggara tahun 2017 menunjukkan peningkatan dari tahun sebelumnya, dari $18.821 .116 \mathrm{~kg}$ di tahun 2016 menjadi $21.057 .951 \mathrm{~kg}$ pada tahun 2017. Kenaikan produksi daging tersebut, termasuk produksi untuk daging sapi potong, yaitu dari 4.412.704 kg menjadi 5.103.796 kg (BPS Sultra, 2018). Permasalahan yang dihadapi tersebut secara perlahan diatasi melalui kegiatan peningkatan produksi peternakan dan penerapan teknologi peternakan.

Melihat potensi sumber daya di Sulawesi Tenggara dalam pengembangan komoditas peternakan, maka potensi unggulan komoditas peternakan di Sulawesi Tenggara dapat ditentukan. Sejauh ini belum diketahui potensi unggulan komoditas peternakan terdapat pada wilayah kabupaten mana. Salah satu indikator penting dalam mengetahui potensi unggulan di suatu wilayah adalah dengan menggunakan Location Quotient (LQ). Menurut Hendarto (2000) bahwa nilai LQ adalah analisis yang membandingkan relatif kemampuan suatu sektor atau sub sektor di daerah tertentu dengan kemampuan sektor atau suksektor yang sama di daerah yang lebih luas. Tujuan penelitian ini adalah diketahuinya potensi unggulan dan penyebaran komoditi sub sektor peternakan dan kemungkinan budidayanya di Provinsi Sulawesi Tenggara.

\section{METODE PENELITIAN}

Metode penelitian yang digunakan adalah dengan menekankan pada analisis data sekunder yang diperoleh dari Biro Pusat Statistik tahun 20162018 yang meliputi volume produksi ternak dari berbagai komoditas peternakan di Sulawesi Tenggara.

Analisis LQ sebagai media atau alat untuk melihat presentasi status dan potensi pengembangan usahatani. LQ merupakan salah satu teknik yang dapat digunakan untuk mengetahui tingkat kemampuan suatu daerah dalam sektor kegiatan (komoditas) tertentu. Selain itu, metode LQ dapat pula digunakan untuk menentukan komoditas 
unggulan (komoditas basis) dalam suatu wilayah dengan dasar ukur bisa produktivitas, luas areal, produksi, pendapatan, kesempatan kerja maupun dasar ukur lainnya. Berdasarkan komoditas unggulan tersebut dapat diturunkan seperangkat masalah dan kendala dalam pengembangannya yang dapat dijadikan sebagai dasar penentuan prioritas penelitian (Syafa'at et al., 2004), dalam analisis ini digunakan dasar ukur berdasarkan jumlah produksi.

Teknik LQ yang digunakan belum mampu memberikan kesimpulan akhir dari sektor-sektor yang teridentifikasi sebagai sektor strategis. Akan tetapi, untuk tahap awal sudah cukup memberi gambaran pada kemampuan atau potensi suatu wilayah dalam sektor yang teridentifikasi (Jumiyanti, 2018).

Rumus LQ dinyatakan sebagai berikut:

$$
\mathrm{LQ}=\frac{(\mathrm{S} 1 / \mathrm{S})}{(\mathrm{N} 1 / \mathrm{N})} \text { atau } \mathrm{LQ}=\frac{(\mathrm{S} 1 / \mathrm{N} 1)}{(\mathrm{S} / \mathrm{N})}
$$

\section{Keterangan: \\ $\mathrm{S} 1=$ Jumlah produksi daging $\mathrm{i}$ di daerah yang diamati (kabupaten) \\ $\mathrm{S}=$ Jumlah produksi daging seluruh kegiatan di daerah yang diamati \\ $\mathrm{N} 1=$ Jumlah produksi daging kegiatan i di daerah yang lebih luas dan daerah yang diamati menjadi bagiannya (kabupaten) \\ $\mathrm{N}=$ Jumlah produksi daging seluruh kegiatan di daerah yang lebih luas, dan daerah yang diamati menjadi bagiannya.}

Hasil analisis LQ menghasilkan 3 (tiga) kriteria sebagai berikut:

LQ >1 Artinya: komoditas tersebut menjadi basis atau sumber pertumbuhan komoditas me-miliki keunggulan kom-paratif, hasilnya tidak saja dapat memenuhi kebutuhan di wilayah sendiri tetapi juga dapat dieksport keluar wilayah.

LQ=1 Artinya : komoditas tersebut tergolong non basis, tidak memiliki keunggulan kom-paratif. Produksinya hanya cukup untuk memenuhi kebutuhan wilayah sendiri.

LQ $<1$ Artinya: komoditas ini juga termasuk non basis. Produksi komoditas di suatu wilayah tidak dapat memenuhi kebutuhan sendiri sehingga perlu pasokan dari luar.

\section{HASIL DAN PEMBAHASAN}

\section{Sumber Daya Alam dan Pertanian}

Sulawesi Tenggara memiliki luas wilayah berupa daratan seluas $38.067,7 \mathrm{~km}^{2}$. Wilayah administrasi Provinsi Sulawesi Tenggara terdiri dari 15 wilayah kabupaten dan 2 kota, diantaranya Buton $\left(1.212,99 \mathrm{~km}^{2}\right)$, Muna $\left(1.922,16 \mathrm{~km}^{2}\right)$, Konawe $\left(4.435,28 \mathrm{~km}^{2}\right)$, Kolaka $\left(3.283,59 \mathrm{~km}^{2}\right)$, Konawe Selatan $\left(5.779,47 \mathrm{~km}^{2}\right)$, Bombana $\left(3.001 \mathrm{~km}^{2}\right)$, Wakatobi $\left(559,54 \mathrm{~km}^{2}\right)$, Kolaka Utara (3.391,67 $\mathrm{km}^{2}$ ), Buton Utara $\left(1.864,91 \mathrm{~km}^{2}\right)$, Konawe Utara $\left(5.101,76 \mathrm{~km}^{2}\right)$, Kolaka Timur $\left(3.634,74 \mathrm{~km}^{2}\right)$, Konawe Kepulauan $\left(867,58 \mathrm{~km}^{2}\right)$, Muna Barat $\left(1.022,89 \mathrm{~km}^{2}\right)$, Buton Tengah $\left(958,31 \mathrm{~km}^{2}\right)$, Buton Selatan $\left(509,92 \mathrm{~km}^{2}\right)$, Kota Kendari $\left(300,89 \mathrm{~km}^{2}\right)$, dan Kota Baubau $\left(221 \mathrm{~km}^{2}\right)$. Beberapa luas penggunaan lahan di Provinsi Sulawesi Tenggara (BPS, 2015) yaitu sawah (3,19\%), tegal/kebun $(5,70 \%)$, ladang/huma (3,52\%), perkebunan $(16,18 \%)$, ditanami pohon/hutan rakyat $(3,73 \%)$, padang penggem-balaan/padang rumput $(2,61 \%)$, sementara tidak diusahakan $(6,07 \%)$, lainnya (tambak, kolam, empang, hutan negara dll $(30,98 \%)$, dan lahan bukan pertanian (jalan, pemukiman, perkantoran, sungai dll $(28,04 \%)$.

\section{Keragaan Komoditas Peternakan}

Subsektor peternakan memegang peranan penting dalam pengembangan agribisnis di Provinsi Sulawesi Tenggara. Komoditas peternakan yang diusahakan rakyat di Provinsi Sulawesi Tenggara terdiri dari 7 jenis yaitu: sapi, kerbau, kuda, kambing, babi, ayam, dan itik. Komoditi yang telah diperdagangkan antar pulau di Sulawesi Tenggara adalah sapi potong. Produksi sapi potong pada tahun 2016 sebesar $4.412 .705 \mathrm{~kg}$ kemudian mengalami peningkatan pada tahun 2017 yaitu sebesar $5.103 .796 \mathrm{~kg}$. Keragaan populasi dan produksi daging ternak di Sulawesi Tenggara dapat dilihat pada Tabel 1. 


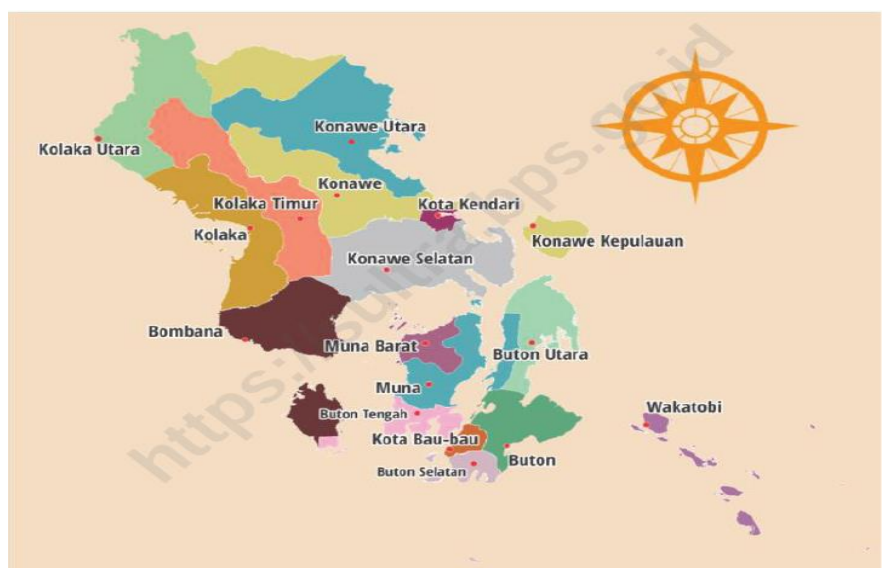

Gambar 1. Peta wilayah Provinsi Sulawesi Tenggara (BPS Sultra, 2018)

Tabel 1. Keragaan perkembangan produksi daging berbagai komoditas pangan di Sultra tahun 2017

\begin{tabular}{|c|c|c|c|c|c|c|c|c|c|}
\hline \multirow[b]{2}{*}{ No. } & \multirow{2}{*}{$\begin{array}{l}\text { Kabupaten/ } \\
\text { Kota }\end{array}$} & \multicolumn{8}{|c|}{ Produksi Daging Ternak $(\mathrm{Kg})$} \\
\hline & & $\begin{array}{c}\text { Sapi } \\
\text { Potong }\end{array}$ & Kerbau & Kuda & Kambing & $\begin{array}{l}\text { Ayam } \\
\text { Buras }\end{array}$ & $\begin{array}{l}\text { Ayam } \\
\text { Petelur }\end{array}$ & $\begin{array}{c}\text { Ayam } \\
\text { Pedaging }\end{array}$ & $\begin{array}{l}\text { Itik/Itik } \\
\text { Manila }\end{array}$ \\
\hline 1 & Buton & 75.174 & - & - & 10.057 & 286.624 & 147 & 12.471 & 12.870 \\
\hline 2 & Muna & 207.097 & 4.136 & - & 17.217 & 1.691 .839 & 21.937 & 67.003 & 14.211 \\
\hline 3 & Konawe & 743.533 & 12.829 & - & 28.058 & 1.262 .674 & 16.366 & 1.113 .970 & 123.914 \\
\hline 4 & Kolaka & 539.518 & 6.569 & 1.500 & 144.233 & 1.606 .597 & 13.562 & 152.488 & 26.446 \\
\hline 5 & Konawe & 873.345 & 1.991 & - & & 1.533 .647 & 17.341 & 752.787 & 43.189 \\
\hline 6 & $\begin{array}{l}\text { Selatan } \\
\text { Bombana }\end{array}$ & 280.396 & 5.308 & 750 & $\begin{array}{l}16.534 \\
52.561\end{array}$ & 938.501 & 6.850 & 11.609 & 7.538 \\
\hline 7 & Wakatobi & 41.038 & - & - & 8.513 & 39.565 & 3.972 & 32.382 & 6.142 \\
\hline 8 & Kolaka Utara & 59.697 & 1.327 & 1.815 & & & & & \\
\hline & & & & & 23.883 & 55.543 & 20.119 & 133.775 & 178.463 \\
\hline 9 & Buton Utara & 82.913 & - & - & 2.391 & 77.483 & 933 & 38.737 & 2.086 \\
\hline 10 & Konawe Utara & 58.290 & 442 & - & 2.378 & 140.529 & 1.832 & - & 1.954 \\
\hline 11 & Kolaka Timur & 59.463 & - & - & 3.251 & 472.692 & 36.630 & 45.400 & 19.811 \\
\hline 12 & $\begin{array}{l}\text { Konawe } \\
\text { Kepulauan }\end{array}$ & 16.080 & - & - & - & 5.846 & - & - & 2.190 \\
\hline 13 & Muna Barat & 203.680 & - & - & 5.275 & 800.460 & 18.431 & 92.260 & 7.219 \\
\hline 14 & Buton Tengah & 165.155 & - & 165 & 12.762 & 244.303 & 733 & 5.00 & 9.930 \\
\hline 15 & Buton Selatan & 14.070 & - & - & 5.705 & 55.829 & 1.590 & 58.250 & 11.385 \\
\hline 16 & Kendari & 1.337.287 & - & 165 & 8.833 & 165.800 & 28.979 & 974.470 & 8.812 \\
\hline 17 & Bau-bau & 347.060 & - & - & 24.199 & 178.770 & 14.652 & 375.000 & 7.326 \\
\hline Sula & esi Tenggara & 5.103 .796 & 32.602 & 4.395 & 365.852 & 9.656 .702 & 204.074 & 3.865 .602 & 483.486 \\
\hline
\end{tabular}

\section{Status Nilai LQ Produksi Daging Berbagai Komoditas Peternakan}

Hasil analisis LQ yang dilakukan terhadap volume produksi daging pada beberapa komoditas peternakan di Sulawesi Tenggara pada selama 3 tahun terakhir dari 2015-2017 menunjukkan 17 kabupaten dengan nilai LQ>1 telah memenuhi ke semua kabupaten mulai dari kabupaten Buton, Muna, Konawe, Kolaka, Konawe Selatan, Bombana, Wakatobi, Kolaka Utara, Buton Utara, Konawe Utara, Kolaka Timur, Konawe Kepulauan, Muna Barat, Buton Tengah, Buton Selatan, Kota Kendari, dan Kota Bau-bau (Gambar 1). Kabupaten Kolaka Utara merupakan kabupaten dengan nilai LQ>1 yang terbanyak dari tahun 2015-2017, sedangkan nilai 
LQ>1 selama 3 tahun terakhir terendah ditunjukkan pada kabupaten Buton Utara (20152017), Buton (2016), Muna (2016), Konawe Selatan (2016), Buton Utara (2016), Muna Barat (2016), Buton Selatan (2016), Kendari (2016), dan Kolaka Timur (2015). Hal ini menandakan bahwa semua kabupaten berpotensi menjadi basis atau sumber pertumbuhan. memiliki keunggulan komparatif. serta hasil komoditas tersebut tidak saja dapat memenuhi kebutuhan untuk wilayah sendiri tetapi juga dapat dieksport keluar wilayah. dan untuk kabupaten Kolaka Utara tidak hanya memiliki keunggulan satu komoditas peternakan saja.

Komoditas peternakan yang unggul di Sulawesi Tenggara berdasarkan analisis nilai
LQ>1 ditunjukkan pada komoditi ayam buras dengan nilai $\mathrm{LQ}=9$ pada tahun 2017 dan 2016. kemudian disusul oleh komoditi sapi potong dan kambing dengan nilai $\mathrm{LQ}=8$ pada tahun 2017 (Gambar 2), sedangkan nilai LQ $>1$ yang terendah terdapat pada komoditi kuda selama 3 tahun terakhir.

Komoditas peternakan yang unggul di Sulawesi Tenggara berdasarkan analisis nilai LQ>1 ditunjukkan pada komoditi ayam buras dengan nilai $\mathrm{LQ}=9$ pada tahun 2017 dan 2016. kemudian disusul oleh komoditi sapi potong dan kambing dengan nilai $\mathrm{LQ}=8$ pada tahun 2017 (Gambar 2). Nilai LQ >1 yang terendah terdapat pada komoditi kuda selama 3 tahun terakhir

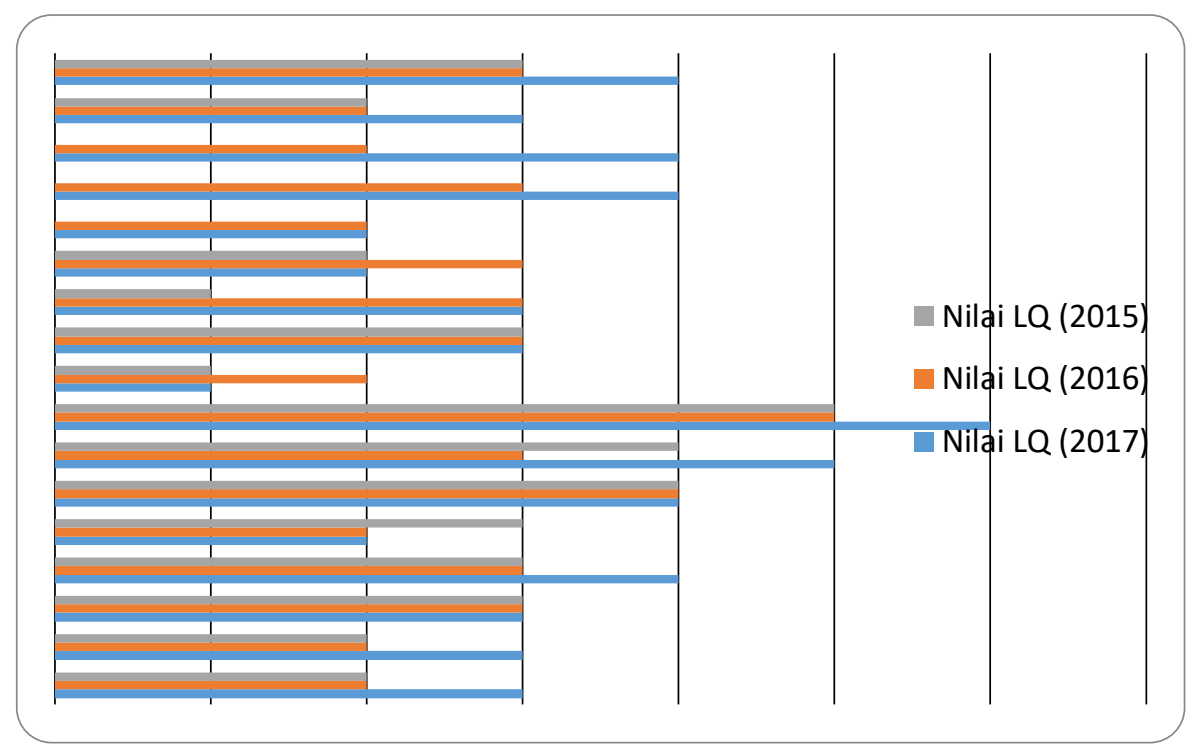

Gambar 1. Nilai LQ>1 Produksi daging komoditas peternakan berdasarkan pendekatan wilayah di Sulawesi Tenggara pada tahun 2015-2017

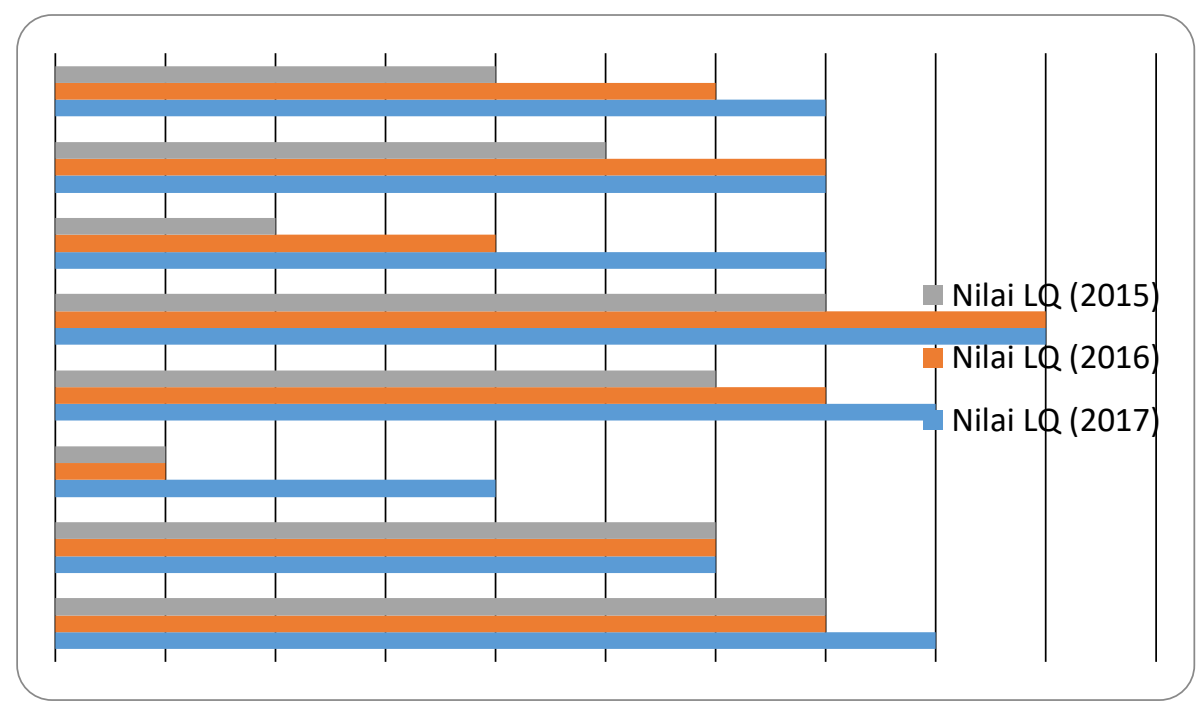

Gambar 2. Nilai LQ>1 Produksi daging komoditas peternakan berdasarkan pendekatan komoditas di Sulawesi Tenggara pada Tahun 2015-2017 
Jika mengacu pada nilai LQ>1, maka dari beberapa komoditas peternakan yang dianalisis. komoditas Ayam Buras merupakan komoditas yang paling unggul. karena sebarannya yang memiliki kriteria LQ>1 terdapat pada 9 kabupaten yakni masing-masing di kabupaten Buton (1,47), Muna $(1,71)$, Kolaka (1,32), Bombana $(1,47)$, Konawe Utara $(1,40)$, Kolaka Timur $(1,51)$, Muna Barat $(1,45)$, Buton Tengah $(1,14)$, dan Buton Selatan $(1,29)$. Komoditas peternakan lainnya yang memiliki keunggulan berdasarkan LQ>1 adalah sapi potong (8 kabupaten), kerbau (6 kabupaten), kuda (4 kabupaten), kambing (8 kabupaten), ayam petelur (7 kabupaten), ayam pedaging (7 kabupaten), dan itik/itik Manila (7 kabupaten). Selengkapnya hasil analisis LQ berbagai komoditas unggulan pada Tabel 2.

\section{Komoditas Peternakan yang Memiliki Keunggulan Komparatif}

Hasil analisis LQ menunjukkan bahwa masing-masing komoditas peternakan memiliki keunggulan komparatif di daerah tertentu. Komoditas ayam buras dari 14 daerah yang mengembangkan terdapat 9 kabupaten yang memiliki nilai LQ>1. Artinya bahwa komoditas ayam buras sudah menjadi basis atau sumber pertumbuhan dan memiliki keunggulan komparatif pada kesembilan daerah tersebut. diantaranya Kabupaten Buton, Muna, Kolaka, Bombana, Konawe Utara. Kolaka Timur, Muna Barat, Buton Tengah, dan Buton Selatan. Produksi daging ayam buras yang dihasilkan tidak saja dapat memenuhi kebutuhan untuk wilayah tersebut. tetapi juga sudah dapat diekspor keluar wilayah.

Hasil analisis LQ juga memperlihatkan bahwa komoditas sapi potong dan kambing masingmasing memiliki keunggulan komparatif di 8 kabupaten yang berbeda. Hal ini menunjukkan bahwa komoditas tersebut tidak saja mampu memenuhi kebutuhan wilayah sendiri tetapi juga mampu diekspor keluar wilayah. Lebih jelasnya sebaran komoditas peternakan yang memiliki nilai LQ>1 ditampilkan pada Tabel 3.

Tabel 2. Hasil analisis LQ terhadap produksi daging beberapa komoditas peternakan unggulan di Sulawesi Tenggara (2017)

\begin{tabular}{|c|c|c|c|c|c|c|c|c|c|}
\hline \multirow[b]{2}{*}{ No. } & \multirow{2}{*}{$\begin{array}{c}\text { Kabupaten/ } \\
\text { Kota }\end{array}$} & \multicolumn{8}{|c|}{ Nilai LQ } \\
\hline & & $\begin{array}{c}\text { Sapi } \\
\text { Potong }\end{array}$ & Kerbau & Kuda & Kambing & $\begin{array}{l}\text { Ayam } \\
\text { Buras }\end{array}$ & $\begin{array}{l}\text { Ayam } \\
\text { Petelur }\end{array}$ & $\begin{array}{c}\text { Ayam } \\
\text { Pedaging }\end{array}$ & $\begin{array}{l}\text { Itik/Itik } \\
\text { Manila } \\
\end{array}$ \\
\hline 1 & Buton & 0,73 & - & - & 1,36 & 1,47 & 0,04 & 0,16 & 1,32 \\
\hline 2 & Muna & 0,40 & 1,24 & - & 0,46 & 1,71 & 1,05 & 0,17 & 0,29 \\
\hline 3 & Konawe & 0,87 & 2,35 & 0 & 0,46 & 0,78 & 0,48 & 1,72 & 1,53 \\
\hline 4 & Kolaka & 0,84 & 1,59 & 2,70 & 3,12 & 1,32 & 0,53 & 0,31 & 0,43 \\
\hline 5 & $\begin{array}{l}\text { Konawe } \\
\text { Selatan }\end{array}$ & 1,04 & 0,37 & 0 & 0,28 & 0,97 & 0,52 & 1,19 & 0,54 \\
\hline 6 & Bombana & 0,83 & 2,46 & 2,58 & 2,17 & 1,47 & 0,51 & 0,05 & 0,24 \\
\hline 7 & Wakatobi & 1,20 & 0 & 0 & 3,49 & 0,61 & 2,92 & 1,25 & 1,90 \\
\hline 8 & $\begin{array}{l}\text { Kolaka } \\
\text { Utara }\end{array}$ & 0,49 & 1,69 & 17,16 & 2,71 & 0,24 & 4,10 & 1,44 & 15,33 \\
\hline 9 & Buton Utara & 1,57 & 0 & 0 & 0,63 & 0,77 & 0,44 & 0,97 & 0,42 \\
\hline 10 & $\begin{array}{l}\text { Konawe } \\
\text { Utara }\end{array}$ & 1,10 & 1,30 & 0 & 0,62 & 1,40 & 0,86 & 0 & 0,39 \\
\hline 11 & $\begin{array}{l}\text { Kolaka } \\
\text { Timur }\end{array}$ & 0,36 & 0 & 0 & 0,27 & 1,51 & 5,55 & 0,36 & 1,27 \\
\hline 12 & $\begin{array}{l}\text { Konawe } \\
\text { Kepulauan }\end{array}$ & 2,58 & 0 & 0 & 0 & 0,49 & 0 & 0 & 3,70 \\
\hline 13 & Muna Barat & 0,70 & 0 & 0 & 0,25 & 1,45 & 1,58 & 0,42 & 0,26 \\
\hline 14 & $\begin{array}{l}\text { Buton } \\
\text { Tengah }\end{array}$ & 1,46 & 0 & 1,69 & 1,57 & 1,14 & 0,16 & 0,06 & 0,92 \\
\hline 15 & $\begin{array}{l}\text { Buton } \\
\text { Selatan }\end{array}$ & 0,22 & 0 & 0 & 1,25 & 1,29 & 0,62 & 1,20 & 1,88 \\
\hline 16 & Kendari & 2,05 & 0 & 0,29 & 0,19 & 0,13 & 1,11 & 1,97 & 0,14 \\
\hline 17 & Bau-bau & 1,42 & 0 & 0 & 1,38 & 0,39 & 1,49 & 2,02 & 0,32 \\
\hline
\end{tabular}

Sumber: Data diolah dari BPS, 2018,

Tabel 3. Sebaran komoditas peternakan dengan nilai LQ>1 di Sulawesi Tenggara 


\begin{tabular}{|c|c|c|c|}
\hline No & Komoditas & Kabupaten & Keterangan \\
\hline 1 & Sapi Potong & $\begin{array}{l}\text { Konawe Selatan }(1,04) \text {, Wakatobi }(1,20) \text {, Buton Utara }(1,57) \text {, Konawe } \\
\text { Utara }(1,10) \text {, Konawe Kepulauan }(2,58) \text {, Buton Tengah }(1,46) \text {, Kendari } \\
(2,05) \text {, Bau-bau }(1,42)\end{array}$ & 8 kabupaten \\
\hline 2 & Kerbau & $\begin{array}{l}\text { Muna }(1,24) \text {, Konawe }(2,35) \text {, Kolaka }(1,59) \text {, Bombana }(2,46) \text {, Kolaka } \\
\text { Utara }(1,69) \text {, Konawe Utara }(1,30)\end{array}$ & 6 kabupaten \\
\hline 3 & Kuda & $\begin{array}{l}\text { Kolaka }(2,70) \text {, Bombana }(2,58) \text {, Kolaka Utara }(17,16) \text {, Buton Tengah } \\
(1,69)\end{array}$ & 4 kabupaten \\
\hline 4 & Kambing & $\begin{array}{l}\text { Buton }(1,36) \text {, Kolaka }(3,12) \text {, Bombana }(2,17) \text {, Wakatobi }(3,49) \text {, Kolaka } \\
\text { Utara }(2,71) \text {, Buton Tengah }(1,57) \text {, Buton Selatan }(1,25) \text {, Bau-bau } \\
(1,38)\end{array}$ & 8 kabupaten \\
\hline 5 & Ayam Buras & $\begin{array}{l}\text { Buton }(1,47) \text {, Muna }(1,71) \text {, Kolaka }(1,32) \text {, Bombana }(1,47) \text {, Konawe } \\
\text { Utara }(1,40) \text {, Kolaka Timur }(1,51) \text {, Muna Barat }(1,45) \text {, Buton Tengah } \\
(1,14) \text {, Buton Selatan }(1,29)\end{array}$ & 9 kabupaten \\
\hline 6 & $\begin{array}{l}\text { Ayam } \\
\text { Petelur }\end{array}$ & $\begin{array}{l}\text { Muna }(1,05) \text {, Wakatobi }(2,92) \text {, Kolaka Utara }(4,10) \text {, Kolaka Timur } \\
(5,55) \text {, Muna Barat }(1,58) \text {, Buton Tengah }(1,11) \text {, Buton Selatan }(1,49)\end{array}$ & 7 kabupaten \\
\hline 7 & $\begin{array}{l}\text { Ayam } \\
\text { Pedaging }\end{array}$ & $\begin{array}{l}\text { Konawe }(1,72) \text {, Konawe Selatan }(1,19) \text {, Wakatobi }(1,25) \text {, Kolaka } \\
\text { Utara }(1,44) \text {, Buton Selatan }(1,20) \text {, Kendari }(1,97) \text {, Bau-bau }(2,02)\end{array}$ & 7 kabupaten \\
\hline 8 & $\begin{array}{l}\text { Itik/itik } \\
\text { Manila }\end{array}$ & $\begin{array}{l}\text { Buton (1,32), Konawe }(1,53) \text {, Wakatobi }(1,90) \text {, Kolaka Utara }(15,33) \text {, } \\
\text { Kolaka Timur }(1,27) \text {, Konawe Kepulauan }(3,70) \text {, Buton Selatan } \\
(1,88)\end{array}$ & 7 kabupaten \\
\hline
\end{tabular}

Tabel 4. Potensi pengembangan komoditas peternakan unggulan menurut kabupaten di Sulawesi Tenggara

\begin{tabular}{clll}
\hline No & \multicolumn{1}{c}{ Kabupaten } & \multicolumn{1}{c}{ Komoditas } & Keterangan \\
\hline 1 & Buton & Kambing, Ayam Buras, Itik/itik Manila & 3 komoditas \\
2 & Muna & Kerbau, Ayam Buras, Ayam Petelur & 3 komoditas \\
3 & Konawe & Kerbau, Ayam Pedaging, Itik/itik Manila & 3 komoditas \\
4 & Kolaka & Kerbau, Kuda, Kambing, Ayam Buras & 4 komoditas \\
5 & Konawe Selatan & Sapi Potong, Ayam Pedaging & 2 komoditas \\
6 & Bombana & Kerbau, Kuda, Kambing, Ayam Buras & 4 komoditas \\
7 & Wakatobi & Sapi Potong, Kambing, Ayam Petelur, Ayam Pedaging, & 5 komoditas \\
& & Itik/itik Manila & \\
8 & Kolaka Utara & Kerbau, Kuda, Kambing, Ayam Petelur, Ayam & 6 komoditas \\
& & Pedaging, Itik/itik Manila & 1 komoditas \\
9 & Buton Utara & Sapi Potong & 3 komoditas \\
10 & Konawe Utara & Sapi Potong, Kerbau, Ayam Buras & 3 komoditas \\
11 & Kolaka Timur & Ayam Buras, Ayam Petelur, Itik/itik Manila & 2 komoditas \\
12 & Konawe Kepulauan & Sapi Potong, Itik/itik Manila & 2 komoditas \\
13 & Muna Barat & Ayam Buras, Ayam Petelur & 4 komoditas \\
14 & Buton Tengah & Sapi Potong, Kuda, Kambing, Ayam Buras & 4 komoditas \\
15 & Buton Selatan & Kambing, Ayam Buras, Ayam Pedaging, Itik/itik Manila & 3 komoditas \\
16 & Kendari & Sapi Potong, Ayam Petelur, Ayam Pedaging & 4 komoditas \\
17 & Bau-bau & Sapi Potong, Kambing, Ayam Petelur, Ayam Pedaging & \\
\hline
\end{tabular}

Ayam buras merupakan salah satu ternak unggas lokal yang telah tersebar di Indonesia dan telah banyak dipelihara oleh petani di perdesaan, Pemeliharaan ayam buras di perdesaan bertujuan untuk menghasilkan daging sekaligus telur (Sayuti, 2002). Ayam lokal memiliki potensi besar untuk dikembangkan menjadi industri perunggasan rakyat, sehingga hal ini dapat menjadi perhatian pemerintah dalam bentuk program atau proyek yang dapat mempercepat perkembangan industri ayam lokal (Iskandar, 2006). Hal ini serupa dengan hasil penelitian Iyai et al., (2016) penyebaran ternak di dataran tinggi Pegunungan Arfak Papua Barat dengan nilai $L Q>1$ terbanyak didominasi oleh ayam kampung dan babi diikuti oleh sapi potong dan kambing.

\section{Potensi Pengembangan Berbagai Komoditas Peternakan menurut Kabupaten di Sulawesi Tenggara}

Berdasarkan hasil analisis LQ menunjukkan bahwa potensi pengembangan berbagai komoditas peternakan menurut wilayah, maka daerah yang memiliki keragaman komoditas peternakan tertinggi adalah Kabupaten Kolaka Utara, karena di 
daerah tersebut memiliki 6 komoditas peternakan yang memiliki LQ>1, selanjutnya Kabupaten Wakatobi yang juga memiliki 5 komoditas peternakan dengan nilai LQ>1. Potensi pengembangan komoditas peternakan unggulan menurut kabupaten di Sulawesi Tenggara selengkapkan disajikan pada Tabel 4.

\section{KESIMPULAN}

Potensi pengembangan komoditas peternakan di Sulawesi Tenggara menunjukkan bahwa ayam buras merupakan komoditas peternakan terunggul di Sulawesi Tenggara karena memiliki nilai LQ> 1 yang tersebar di 9 kabupaten, dan kedua adalah komoditas sapi potong dan kambing dengan sebarannya di 8 kabupaten yang berbeda. Potensi pengembangan komoditas peternakan menurut kabupaten di Sulawesi Tenggara menunjukkan bahwa kabupaten yang memiliki keragaman komoditas peternakan tertinggi adalah kabupaten Kolaka Utara, karena memiliki 6 komoditas yang memiliki nilai LQ>1, kedua adalah kabupaten Wakatobi yang memiliki 5 komoditas dengan nilai LQ>1. Hasil penentuan komoditas peternakan unggulan disetiap kabupaten dapat menjadi peluang bagi masing-masing kabupaten untuk terpilih menjadi wilayah pengembangan komoditas peternakan unggulan tingkat provinsi Sulawesi Tenggara.

\section{DAFTAR PUSTAKA}

[BPS] Badan Pusat Statistik. 2015. Luas Penggunaan Lahan di Sulawesi Tenggara Menurut Kabupaten/Kota (ha) 2014. https://sultra,bps,go,id/statictable/2018/02/1 5/721/luas-penggunaan-lahan-di-sulawesitenggara-menurut-kabupaten-kota-ha2014.html. [9 Oktober 2019].

[BPS Sultra] Badan Pusat Statistik Provinsi Sulawesi Tenggara. 2016. Provinsi Sulawesi Tenggara Dalam Angka 2015. Badan Pusat Statistik Provinsi Sulawesi Tenggara. Kendari.

[BPS Sultra] Badan Pusat Statistik Provinsi Sulawesi Tenggara. 2017. Provinsi Sulawesi Tenggara Dalam Angka 2016. Badan Pusat Statistik Provinsi Sulawesi Tenggara. Kendari.

[BPS Sultra] Badan Pusat Statistik Provinsi Sulawesi Tenggara. 2018. Provinsi Sulawesi Tenggara Dalam Angka 2017. Badan Pusat Statistik Provinsi Sulawesi Tenggara. Kendari.
Hendarto, R.M. 2000. Analisis potensi daerah dalam pembangunan ekonomi. Fakultas Ekonomi Universitas Diponegoro. Semarang.

Iskandar, S. 2006. Strategi Pengembangan Ayam Lokal. Wartazoa 16(4):190-197.

Iyai, D.A., A.L. Sumule, M. Sagrim, \& M. Baransano. 2016. Asesmen cepat potensi komoditas unggulan peternakan dataran tinggi Pegunungan Arfak, Papua Barat. Jurnal Sain Peternakan Indonesia 11(2):8288 ,

Jumiyanti, K.R. 2018. analisis location quotient dalam penentuan sektor basis dan non basis di Kabupaten Gorontalo. Gorontalo Development 1(1):29-43.

[Kementerian PPN/Bappenas] Kementerian Perencanaan Pembangunan Nasional/Badan Perencanaan Pembangunan Nasional. 2017. Profil dan Analisis Daerah Provionsi Sulawesi Tenggara, 2017. Kedeputian Bidang Pengembangan Regional, Kementerian Perencanaan Pembangunan Nasional/ Badan Perencanaan Pembangunan Nasional. Jakarta. Https://simreg. Bappenas.go.id/assets/temaalus/document/p ublikasi/dokpub/prada_provinsi_sulawesi_te nggara.pdf [9 Oktober 2019].

[Kementerian PPN/Bappenas] Kementerian Perencanaan Pembangunan Nasional/Badan Perencanaan Pembangunan Nasional. 2015. Seri Analisis Pembangunan Wilayah Provinsi Sulawesi Tenggara 2015. Kedeputian Bidang Pengembangan Regional, Kementerian Perencanaan Pembangunan Nasional/ Badan Perencanaan Pembangunan Nasional. Jakarta. http://simreg.bappenas.go.id/assets/ temaalus/document/publikasi/dokpub/analisis \%20provinsi\%20sulawesi\%20tenggara\%202 015_ok.pdf [9 Oktober 2019].

[Kementan] Kementerian Pertanian RI. 2015. Rencana Strategis Kementerian Pertanian Tahun 2015-2019. Kementerian Pertanian RI. Jakarta.

Sayuti, R. 2002. Prospek pengembangan agribisnis ayam buras sebagai usaha ekonomi di pedesaan. Forum Penelitian Agro Ekonomi 20(1):40-49.

Sudana, W., N. Ilham, D.K.S. Swastika, \& R.N. Suhaeti. 1999. Metodologi Penelitian dan Pengkajian Sosial Ekonomi Pertanian. Tim 
Badan Penelitian dan Pengembangan Pertanian. Jakarta. kecamatan di Kabupaten Purworejo. Mediagro 7(2):11-18.

Syafa'at, N., M. Maulana, \& P. Simatupang. 2004. Metode Kuantitatif Penentuan Prioritas Penelitian dan Pengkajian dalam Kerangka Arah Kebijakan Pembangunan Pertanian Nasional dan Daerah: Pendekatan Analisis Location Quotient Sederhan (Simple Location Quotient). Modul Penelitian Analisis Finansial dan Ekonomi Bagi Pengembangan Sistem dan Usahatani Agribisnis Wilayah. Kerja sama Puslitbang Sosial Ekonomi Pertanian dan Proyek Pengkajian Teknologi Partisipatif (PAATP), Badan Litbang Pertanian. Bogor.

Wicaksono, I.A. 2011. Analisis location quotient sektor dan subsektor pertanian pada 